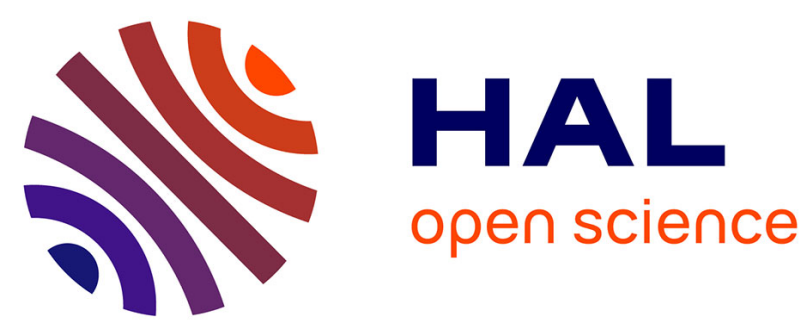

\title{
ESR/U-series dates on Equus teeth from the Middle Pleistocene Acheulean site of Cueva del Angel, Spain
}

C. Falguères, B Ghaleb, O. Tombret, E Ben Arous, Maïlys Richard, A. M. Moigne, T. Saos, M Frouin, M Caparros, C Barroso-Ruiz

\section{- To cite this version:}

C. Falguères, B Ghaleb, O. Tombret, E Ben Arous, Maïlys Richard, et al.. ESR/U-series dates on Equus teeth from the Middle Pleistocene Acheulean site of Cueva del Angel, Spain. Quaternary Geochronology, 2019, 49, pp.297-302. 10.1016/j.quageo.2018.02.003 . hal-02376440

\author{
HAL Id: hal-02376440 \\ https://hal.science/hal-02376440
}

Submitted on 22 Nov 2019

HAL is a multi-disciplinary open access archive for the deposit and dissemination of scientific research documents, whether they are published or not. The documents may come from teaching and research institutions in France or abroad, or from public or private research centers.
L'archive ouverte pluridisciplinaire HAL, est destinée au dépôt et à la diffusion de documents scientifiques de niveau recherche, publiés ou non, émanant des établissements d'enseignement et de recherche français ou étrangers, des laboratoires publics ou privés. 


\title{
ESR/U-series dates on Equus teeth from the Middle Pleistocene Acheulean site of Cueva del Angel, Spain
}

\author{
C. Falguères ${ }^{1}$, B. Ghaleb ${ }^{2}$, O. Tombret ${ }^{1}$, E. Ben Arous ${ }^{1}$, M. Richard ${ }^{1-3}$, A.M. Moigne ${ }^{1}, \mathrm{~T}$. \\ Saos $^{1}$, M. Frouin ${ }^{4}$, M. Caparros ${ }^{1}$, C. Barroso-Ruiz ${ }^{5}$ \\ ${ }^{1}$ UMR7194, Muséum national d’histoire naturelle, 1, rue R. Panhard, 75013, Paris, France \\ ${ }^{2}$ GEOTOP-UQAM-McGILL, Université du Québec à Montréal, Montréal, H3C 3P8, Canada \\ ${ }^{3}$ UMR5060, Université Bordeaux-Montaigne, 33607, Pessac cedex, France \\ ${ }^{4}$ Research Laboratory for Archaeology and the History of Art, Oxford University, Oxford, OX1 3QY, United \\ Kingdom \\ ${ }^{5}$ Fundación Instituto de Investigación de Prehistoria y Evolución Humana, Plaza del Coso 21, 14900, Lucena \\ Corresponding author: Christophe Falguères, christophe.falgueres@mnhn.fr
}

\begin{abstract}
:
The Cueva del Angel (Lucena, Spain) is an open-air archaeological site with a sedimentary sequence remnant of a collapsed rock shelter which was part of a still active karst complex. The lithic assemblage consists essentially of abundant retouched tools including 46 identified handaxes along with non-modified flakes, and is associated with faunal remains dominated by Equus ferus and other large bovids and cervids. A large proportion of bones has undergone intense anthropic actions and been subjected to intense fire, thus evidencing sustained use of animal meat resources by humans.

In order to better ascertain the chronological framework of the site, we dated several proxies. Various speleothem samples were processed by U-series using a coupled induced plasma mass spectrometer (ICPMS-MC). The resulting isotopic ratios are beyond the secular equilibrium and show that these samples do not appear to be in direct stratigraphic relation with the archaeological sequence.

Nine Equus teeth were analysed by the combined ESR/U-series method. These samples were taken from Unit I to Unit XVI representing at least 2.5 meters of stratigraphic depth and approximately $90 \%$ of the infilling. Many of the dated samples are burnt given that more than $85 \%$ of the faunal remains exhibit traces of fire exposure.
\end{abstract}


The bone retouchers, for which a comparative analysis with other sites has been published (Moigne et al., 2016), were probably produced during the Marine Isotope Stage (MIS 11-5) chronological interval corresponding to the later part of the Middle Pleistocene, inference that is in agreement with the palaeontological assemblage of the site. The radiometric results presented here are consistent and indicate a range from 323 to $179 \mathrm{ka}$, suggesting that a major part of the sedimentary infilling coinciding with the human occupation was contemporaneous with the MIS 9 to 7 time period.

Key-words: Combined ESR/U-series; Middle Pleistocene; Cueva del Angel; Acheulean; Spain

\section{Highlights}

The Cueva del Angel site is an important Middle Pleistocene site of the Iberian Peninsula evidencing bifacial Acheulean industry in a cave environment.

More than $85 \%$ of the fauna has been subjected to intense fire throughout the archaeological sequence.

The dating results suggest a MIS 9 to MIS 7 period of human occupation. 


\section{Introduction}

The Cueva del Angel archaeological site is situated on the outskirt of the city of Lucena in the province of Cordoba, Spain (Fig. 1). It is located in the Sierra de Araceli geologically originating from Mesozoic carbonates affected by faults and joints that contributed to the formation of various cavities. It is an open-air archaeological sedimentary sequence remnant of a collapsed rock shelter which was part of a still active karst complex. The archaeological context is rich with a lithic assemblage consisting of thousands of artefacts associated with thousands of faunal remains dominated by herbivores in which Equus ferus is the most abundant, and other large bovids (Bos primigenius and Bison priscus), cervids (Cervus elaphus and Dama), and to a lesser extent other large mammals such as Stephanorhinus hemitoechus and Palaeoloxodon antiquus. Carnivores are represented by Ursus arctos, Canis lupus, Felis silvestris and Lynx pardinus spelaeus but their presence is limited and punctual. Among the thousands of lithics artefacts found in stratigraphical context, $97 \%$ are made of flint. A large proportion of blades longer than $2 \mathrm{~cm}$ are unhearthed from all the layers suggesting a continuous human occupation. Scrapers and denticulates dominate the assemblage (70 \%), followed by notches (20\%), and a few points and Upper Palaeolithic type tools. About 50 handaxes were found in the entire stratigraphy. A large proportion of lithic cores, found in stratigraphical position, were knapped by means of a discoïd "débitage" (Barroso et al., 2011). The faunal artefacts density is very high per square meter with a large proportion of bones having undergone intense anthropic actions and been subjected to intense fire, thus evidencing a sustained use of animal meat resources by humans.

Several Equus teeth sampled in the stratigraphic layers were analyzed by ESR/U-series in order to assess the chronostratigraphy of the site and better understand the succession of periods of human occupation. 


\section{The site}

The archaeological site opens up on the southern flank of the Sierra and represents a small part of the karst complex which comprises a nearby cavity and a more than $100 \mathrm{~m}$ deep sinkhole underneath (Barroso et al., 2011).

The $5 \mathrm{~m}$ thick archaeological sequence is composed of 17 levels or beds without hiatus and the sedimentary infilling (Fig.2) has been divided into three major units according mainly to mineralogical composition and grain-size distribution as follows from top to bottom:

Unit I from $\mathrm{Z}=-215$ to $-265 \mathrm{~cm}$ is constituted for more than $80 \%$ of fine grain sand, silt and clay, and some coarse structure with gravel and blocks reaching $5 \mathrm{~cm}$ diameter. This unit contains archaeological remains.

Unit II from $Z=-265$ to $-450 \mathrm{~cm}$ is also for its major part made of fine grain matrix (40 \% sand, $27 \%$ silt and $11 \%$ clay) and gravel (22\%). The great majority of lithic and faunal artefacts was found in this unit. The middle part is constituted of black horizons and carbonate stratified beds while its base includes limestone clasts and concretions.

Unit III from $Z=-450$ to $-580 \mathrm{~cm}$ is entirely made of a fine matrix composed of sand (34 \%), silt (47\%) and clay (17\%), and less than $5 \%$ of gravel. The upper part is formed by concretions and black soils. At the base, a thick stalagmitic formation is much older than the layers containing archaeological material such as burnt bones and flint artefacts including some handaxes and limestone blocks. This speleothem lies on the bedrock as shown in Barroso et al., 2011, (Fig.3 p.108). The lowest levels are visible in the mining well of the site representing a drilling survey dug in the $18^{\text {th }}$ century to ascertain whether travertine could be used in the construction of buildings. 
The extensive combustion structure throughout practically all the sequence shows different types of colour of sediments, ranging from brown and black to grey and white, due to the presence of a lot of bone splinters and weathered coarse gravels appearing as heterogeneous. The large hearth structure of more than $2 \mathrm{~m}$ diameter includes black ashes, layers with red rubefaction and carbonated levels. The studies performed on clay mineralogy suggest that a thermal event (more than $500^{\circ} \mathrm{C}$ ) could be responsible for the degradation of illite and smectite, and possibly the loss of kaolinite (Barroso et al., 2011).

\section{Material and methods}

The principles of the U/Th dating method lie on the difference of solubility between uranium and thorium. Generally, well-crystallized speleothems often behave as closed systems with respect to uranium, taking up trace amounts of uranium as they form, but no Th. The amount of radiogenic ${ }^{230} \mathrm{Th}$ formed in ratio to its parent ${ }^{234} \mathrm{U}$ yields the age of formation of the speleothem (Ivanovich et Harmon, 1992, Bourdon et al., 2003).

The chronology of the site was first based on a preliminary U-series dating of calcite flowstone which partially covers the archaeological sequence (zone L6, Bed VIII) and provided a minimum age of 120ka (CA9504) for the faunal and the lithic assemblages (Tab.1). It was demonstrated subsequently that this sample could not be used as minimum age for the archaeological sequence (Barroso et al., 2014). Recently new samples were taken in the same formation and analysed by MC-ICPMS at Geotop, Montreal. The results yielded older ages confirming that this formation is not in stratigraphical relation with the archaeological context. Two other samples taken 20 years ago and coming from the same formation as CA9504, showed already an isotopic equilibrium indicating an old age (Tab.1). The combined ESR/U-series (US-ESR) model takes into account both ESR and U-series data including radioelement contents, isotopic ratios, palaeodoses, cosmic dose and external 
gamma-dose rate allowing the reconstruction of the uranium uptake history in each dental tissue using a specific U-uptake parameter (p-value) (Grün et al., 1988). The application of the combined approach has been used for dating the entire Middle Pleistocene on both human and animal teeth (Grün, 2006; Falguères et al., 2010). The model cannot account for uranium loss though a new model, called the Accelerating uptake model, AU-ESR, allows an extension to samples exhibiting slight uranium leaching (Shao et al., 2012). In this study, the uranium content in some teeth is very low and is at the limit of applicability of the combined method.

Nine herbivorous teeth were selected from the entire sequence (Fig. 2) and prepared in the laboratory for analyses. Enamel, dentine and cement when present, were separated mechanically and their radioisotope contents measured by alpha-ray spectrometry in the Paris laboratory, using standard methods (Bischoff et al., 1988), and gamma-ray spectrometry (Yokoyama et NGuyen, 1980).

A part of the enamel, after cleaning its surface on both sides (inner and outer sides) to eliminate the effect of external alpha radiation, was ground, sieved and the 100-200 $\mu \mathrm{m}$ fraction split into 10 aliquots. Nine of these aliquots were irradiated with a calibrated ${ }^{60} \mathrm{Co}$ gamma-ray source from 40 to 1600 Gy. The ESR measurements were performed on EMX Bruker ESR spectrometer at MNHN, Paris, using the following parameters: $1 \mathrm{~mW}$ microwave power, $0.1 \mathrm{mT}$ modulation amplitude, room temperature $\left(19^{\circ} \mathrm{C}\right), 10 \mathrm{mT}$ scan range, $4 \mathrm{~min}$ scan time and $100 \mathrm{kHz}$ frequency modulation, at least three measurements were repeated for each dose on different days. The equivalent doses $\left(D_{E}\right)$ were determined from the asymmetric enamel T1-B2 signal at g = 2.0018 (see Fig.4SI in supplementary Information), (Grün et al., 2008) and fitted from the experimental data using an exponential function (SSE) with Microcal Origin Pro 8 software with $1 / \mathrm{I}^{2}$ weighting. The $\mathrm{D}_{\mathrm{E}}$ were calculated from mean 
values obtained from 4 repeated measurements for each aliquote. ESR age calculations were carried out with the ESR-DATA program of Grün, (2009) which uses an alpha efficiency of $0.13 \pm 0.02$ (Grün and Katzenberger-Apel, 1994) and Monte-Carlo beta attenuation factors (Brennan et al. 1997) based on the thickness of the tooth enamel and outer layers removed. The cosmic dose rate evaluation was performed according to Prescott and Hutton (1994). The thickness between the upper layers and the top of the roof is estimated to be 6 meters and this value has been taken into account in the calculation.

A $0 \%$ water content in the enamel has been used for the calculation. For dentine and cement, the associate error of $5 \pm 3 \%$ water has been used. For the sediment the associate error of 12 $\pm 5 \%$ has been used and determined by measuring the dry weight after putting the wet sediment in an oven at $35^{\circ} \mathrm{C}$.

The uranium content in the teeth is very low. Equilibrium in the ${ }^{238} \mathrm{U}$-series was used in enamel and a $0.5 \pm 0.3$ ratio was used in dentine and cement.

Gamma-ray spectrometry was used to determine the sediment radioisotopes $\mathrm{U}$, Th and $\mathrm{K}$ which contain the teeth. The dose rate was calculated according to Adamiec and Aitken (1998) and no U-series disequilibrium was observed in the sediments by Gamma-ray spectrometry.

\section{Results and discussion}

Table 1 shows U contents, isotopic ratios and U-series ages for samples on which MC-ICPMS was performed (CA\#1 and CA\#6) and for those analyzed by alpha-ray spectrometry (CA9504, CA9507a and CA9507b). All results suggest a great antiquity of these speleothems excepting for CA9504 which formed during MIS5. This formation including the 5 analyzed samples of different ages, some of them being very old, grew independently from the 
archaeological sequence. The layer in which CA9504 was taken is superficial and formed during the last interglacial period, more humid. It represents the last part of growth of a relatively large speleothem which began to growth at least before 500000 years ago with long interruptions when the climate was dryer. These results confirm that there is no stratigraphical relation between calcite layers and the archaeological infilling although the speleothem covers partially the sequence. It means that the karst was active at least more than 450000 years ago. Table 2 shows the isotopic ratios of the different tissues for each tooth excepting for CA1308 for which the error range was too large for calculating an age. The values given in italic are provided with a large error range. For each sample, U, Th, K values of sediment taken close to each sample is presented in the Table 2. For CA1306 and CA1307 which belong to the same mandible and were found very close each from other, the same sediment was used. For A1311 and CA1312 samples, we got the results of ICPMS measurements of sediments, performed independently at Oxford lab for OSL analyses, which are close to those measured by high resolution low background gamma ray spectrometry in our lab. Table 3 shows uranium contents, $D_{E}, p$-values and ages of the teeth. $U$ content is very low and ranges between 0.030 and $0.160 \mathrm{ppm}$ in the enamel and between 0.310 and $3.520 \mathrm{ppm}$ in the dentine and cement tissues. We reach the lower limits for calculating an age when U-series are performed using classic alpha-ray counting as it is the case in this study. The internal alpha and beta doses contribute for 3 to $8 \%$ excepting for the CA1301 sample which has an internal dose around $15 \%$ of the total dose. The $\mathrm{D}_{\mathrm{E}}$ range between 63 and $89 \mathrm{~Gy}$ excepting for three teeth (CA1306, CA1307 and CA1310) for which $\mathrm{D}_{\mathrm{E}}$ are around $110 \mathrm{~Gy}$. New $\mathrm{D}_{\mathrm{E}}$ calculations subtracting the last two most irradiated aliquots according the recommendations made in Duval and Grün (2016), show no significant changes (see table 4SI and text in supplementary information). All the analyzed teeth are burnt and the separation of the tissues was sometimes 
extremely difficult. Several were covered by burnt sediment, very well mixed with the cement tissue. A Dentine-Enamel-Dentine system was adopted (teeth with an asterisk in Table 3) when it was not possible to collect the cement for analyse. However, the impact is negligible provided that the $\mathrm{U}$ content in the dentine and enamel is low.

Radiometric results are in agreement with the depth of the stratigraphy except for two teeth, CA1311 and CA1312, at the bottom of the sequence presenting younger ages than the other ages. The ages obtained by using either sediments measured by gamma ray or those analyzed by ICPMS (Table 2) are in the error range $(165+14 /-12$ ka instead $179+15 /-14$ ka for CA1311, and $204+17$ / -21 ka instead $232+20 /-18$ ka for CA1312). Fig 3 shows the ages versus the depth of the sequence.

ESR-US ages show a clear distribution mode around 200-250 ka coeval with MIS7, while two teeth (CA1306 and CA1307) coming from the same mandible exhibit older ages at $300 \mathrm{ka}$ and probably might represent the real age of the archaeological deposits of level VI. A third tooth, CA1310 found in the G8 square yielded also a $\mathrm{D}_{\mathrm{E}}=113 \mathrm{~Gy}$ close to those of CA1306 and CA1307, 109 and 112 Gy respectively. However, the measurement of uranium content in enamel is very difficult to ascertain and the dose rate is given with a $25 \%$ error resulting in a large error on the age. For the CA1308 sample it was not possible to obtain a significant age because the error range on the isotopic ratios is too large.

All the teeth have very low uranium content probably due to the low $\mathrm{U}$, Th, $\mathrm{K}$ contents in the karst of the Sierra. In the measured sediments, U content range between 0.5 and $1.2 \mathrm{ppm}$, Th content between 0.8 and $3.2 \mathrm{ppm}$ and $\mathrm{K}$ content (\%) between 0.1 and 0.5 . The fact that the teeth underwent an intense combustion could also explain these low concentrations, although the relation between high temperature and low uranium content is not demonstrated. As shown in Supplementary information (Fig4SI), the ESR signals do not present any 
modification due to heating. Burnt teeth coming from a hearth at Qesem cave, Israel, presented ESR-US ages similar to those which were taken in coeval unburnt layers. The U content in burnt teeth was ten times lower than U content in unburnt tissues (Falguères et al., 2016). It is clear that the hearths both in Qesem cave and in Cueva del Angel reflect unequivocally periods of human occupations during MIS 9.

\section{Conclusions}

The Cueva del Angel has yielded more than 5000 lithic and 9000 faunal palaeontological remains. It is an important reference of the Middle Pleistocene Acheulean industry in a cave environment in the southern part of Spain. This site represents one of the largest archaeological combustion structures in Europe with more than 3 meter extension. The intense fragmentation (95\%) of the bones for marrow extraction and the high proportion of burnt lithic artefacts confer to the site an original identity and outstanding interest for the study of prehistoric human occupation during extended periods of time.

The recovered and studied paleontological assemblage, dominated by large herbivores such as horses, bisons and cervids, suggests a chronological period ranging from the end of the Middle Pleistocene to the beginning of the Upper Pleistocene, from MIS 11 to MIS 5 (Moigne et al., 2016). The new radiometric data presented in this work, constrain the human occupation during a period ranging from MIS 9 to MIS 7. The scarcity of carnivores (less than $4 \%$ of the taxonomically determined remains without bears), the quasi absence of rodents, the absence of important stratigraphic gap and the agreement of the new dates with the biochronological data suggest that the human occupation was uninterrupted and constant between 320 and 180 ka. MIS 8 begins with a high stand level (MIS 8-5) with approximately the same climatic conditions as MIS 9 reducing the "cold” period to about 20 ka between 270 and 250 ka (Lisiecki and Raymo, 2007). Therefore, we may infer that when cold conditions 
prevailed in Spain during MIS 8, faunas could find refuge in Andalucia where climatic conditions were probably less cold, as suggested by the herpetofauna (Barroso et al., 2011). The Cueva del Angel archaeological site is one of the oldest sites of the Iberian Peninsula in which bone retouchers were found along with lithic assemblages in such an extensive combustion context. It is coeval with the upper layers of the Ambrona archaeological sequence in Spain (Falguères et al., 2006), and with Orgnac3 and Cagny l'Epinette in France where Levallois technology is observed and dated at around 300 ka (Michel et al., 2011; Falguères et al., 1988; Laurent et al., 1994; Bahain et al., 2007).

\section{Acknowledgements}

We thank all the team members who excavate at Cueva del Angel and especially those who helped in the sediment sampling. 


\section{References}

Adamiec, G., Aitken, M.J., 1998. Dose-rate conversion factors: update. Ancient TL 16, 37-50.

Bahain J.J., Falguères C., Laurent M., Voinchet P., Dolo J.M., Antoine P., Tuffreau A., 2007. ESR chronology of the Somme River Terrace system and first human settlements in northern France. Quaternary Geochronology 2, 356-362.

Barroso Ruiz, C., Botella Ortega, D., Caparrós, M., Moigne, A.M., Celiberti,V., Testu, A., Barsky, D., Notter, O., Riquelme Cantal, J.A., Pozo Rodríguez, M., Carretero León, M.I., Monge Gómez, G., Khatib, S., Saos, T., Gregoire, S., Bailón, S., García Solano, J.A., Cabral Mesa, A.L., Djerrab, A., Hedley, I.G., Abdessadok, S., Batalla Llasat, G., Astier, N., Bertin, L., Boulbes, N., Cauche, D., Filoux, A., Hanquet, C., Milizia, C., Moutoussamy,J., Rossoni, E., Verdú Bermejo, L., Lumley de, H., 2011. The Cueva del Angel (Lucena,Spain): An Acheulean hunters habitat in the South of Iberian Peninsula. Quaternary International. 243, 105-126.

Barroso Ruiz, C., Moigne, A.M., Caparros, M., Celiberti, V., Solano, J.G., Monge-Gomez, G., Monclova, A., 2014. El Achelense de la Cueva del Angel (Lucena, Cordoba). In : Los cazadores recolectores del PLeistoceno y del Holoceno en Iberia y el estrecho de Gibraltar : Estado actual del conocimiento del registro arqueologico. Universidad de Burgos, Ed. Robert Sala Ramos, 451-463.

Bischoff, J.L., Rosenbauer, R.J., Tavoso, A., Lumley, H. de, 1988. A test of uranium-series dating of fossil tooth enamel: Results from Tournal cave, France, Applied Geochemistry 3, 135-141.

Bourdon, B., Henderson, G.M., Lundstrom, C.C., Turner, S., 2003. U-series geochemistry. Reviews in Mineralogy and Geochemistry, 52, 1-656.

Brennan, B.J., Rink, W.J., McGuirl, E.L., Schwarcz, H.P., Prestwich, W.V., 1997. Beta doses in tooth enamel by "One Group" theory and the Rosy ESR dating software. Radiat. Meas. 27, 307-314.

Duval, M. Grün, R., 2016. Are published ESR dose assessments on fossil tooth enamel reliable? Quaternary Geochronology 31:19-27.

Falguères, C., Shen, G., Yokoyama, Y., 1988. Datation de l'Aven d’Orgnac III : comparaison par les méthodes de la résonance de spin électronique (ESR) et du déséquilibre des familles de l'uranium. L’Anthropologie, 92, 727-730.

Falguères C., Bahain J.J., Perez-Gonzalez A., Mercier N., Santonja M., Dolo J.M., 2006. The Lower Acheulian site of Ambrona, Soria (Spain): ages derived from a combined ESR/Useries model. Journal of Archaeological Science, 33, 149-157.

Falguères C., Bahain J.J., Duval M., Shao Q., Han F., Lebon M., Mercier N., Perez-Gonzalez A., Dolo J.M., Garcia T., 2010. A 300-600 ka ESR/U-series chronology of Acheulian sites in Western Europe. Quaternary International, 223-224, 293-298. 
Falguères C., Richard M., Tombret O., Shao Q., Bahain J.J., Gopher A., Barkai R., 2016. New ESR/U-series dates in Yabrudian and Amudian layers at Qesem. Quaternary International, 398, 6-12.

Grün, R., 2006. Direct dating of human remains. Yearbook of Physical Anthropology 49: 248.

Grün, R., 2009. The DATA program for the calculation of ESR age estimates on tooth enamel. Quaternary Geochronology 4, 231-23

Grün, R., Joannes-Boyau, R., Stringer, C., 2008. Two types of $\mathrm{CO}_{2}{ }^{-}$radicals threaten the fundamentals of ESR dating of tooth enamel. Quaternary Geochronology 3, 150-172.

Grün, R., Schwarcz, H. P., Chadam, J.M., 1988. ESR dating of tooth enamel: coupled correction for U-uptake and U-series disequilibrium. Nucl. Tracks Radiat Measur. 14, 237241.

Grün, R., Katzenberger-Apel, O., 1994. An alpha irradiator for ESR dating. Ancient TL 12, 35-38.

Ivanovich, M. Harmon, R.S., 1992. Uranium-series Disequilibrium : Applications to Earth, Marine and Environmental Sciences, 2nd Edition. Oxford, Clarendon Press.

Laurent M., Falguères C., Bahain J.J. \& Yokoyama Y., 1994. Géochronologie du système de terrasses fluviatiles quaternaires du bassin de la Somme par datation RPE sur quartz, déséquilibres des familles de l'uranium et magnétostratigraphie. C. R. Acad. Sci. Paris , 318, 521-526.

Lisiecki, L.E., Raymo, M.E., 2007. Plio-Pleistocene climate evolution: trends and transitions in glacial cycle dynamics. Quaternary Science Reviews, 26, 56-69.

Michel, V., Shen, G., Shen, C.C., Fornari, M., Vérati, C., Gallet, S., Sabatier, D., 2011. Les derniers Homo heidelbergensis et leurs descendants les néandetalien: datation des sites d’Orgnac 3, du Lazaret et de Zafarraya. C.R. Palevol, 10, 577-587.

Moigne, A.M., Valensi, P., Auguste, P., Garcia Solano, J., Tuffreau, A., Lamotte, A., Barroso Ruiz, C., Moncel, M.H., 2016. Bone retouchers from Lower Palaeolithic sites : Terra Amata, Orgnac 3, Cagny-L’Epinette and Cueva del Angel. Quaternary International. 409, 195-212.

Prescott, J.R., Hutton, J.T., 1994. Cosmic ray contributions to dose rates for luminescence and ESR dating: large depths and long-term time variations. Radiat. Meas. 23, 497-500.

Shao Q., Bahain J.J., Falguères C., Dolo J.M., Garcia T., 2012. A new U-uptake model for combined ESR/U-series dating of tooth enamel. Quaternary Geochronology, 10, 406-411. 
Yokoyama Y., NGuyen, H.V., 1980. Direct and non destructive dating of marine sediments, manganese nodules and corals by high resolution gamma-ray spectrometry. In: Isotope marine chemistry, Goldberg E.D. et al., (eds), Uchida Rokakuho, Tokyo, 259-289. 


\section{Figure caption}

Figure 1: Localisation of the site of Cueva del Angel, Spain.

Figure 2: Synthetic log of the stratigraphic sequence. The Unit I is not represented on the figure because no sample were taken from the upper part except for the calcite samples (in red) that are located without any direct stratigraphic relation with the archaeological sequence. The dotted line represents a theoric upper limit of the infilling. The thickness of different units is not taken into consideration. All the analysed teeth (in green) are represented in the figure.

Figure 3: Radiometric ages versus depth and according to the MIS (Lisiecki et al., 2007). In clear blue, the US ages are represented with their error range (one sigma).

\section{Table caption}

Tab 1: Uranium content, isotopic ratios and ages of calcite samples. Three of them were taken 20 years ago and CA\#1 and CA\#6 were taken recently. All samples resent ${ }^{230} \mathrm{Th} /{ }^{232} \mathrm{Th}$ higher than 20 and no correction was brought for the age determination.

Tab 2: Isotopic ratios in the different tissues of each tooth of the Cueva del Angel, and U, Th, $\mathrm{K}$ content in the equivalent sediments. The results presented in italic have large error due to very low uranium content in both tissues. For samples taken in the well (CA1311 and CA1312), two measurements were made using ICPMS independently for OSL by Oxford Lab for the equivalent sediments. The $\mathrm{U}$, Th, $\mathrm{K}$ results are similar to the gamma spectrometry results excepting for K of CA1311 and Th of CA1312 which are higher by ICPMS.

Tab 3: Uranium content, DE, dose rates and ESR/U-series ages obtained on herbivorous teeth of Cueva del Angel. Samples with one asterisk are considered with a dentine-enamel-dentine system. For CA1308**, it was not possible to calculate an age (see text for details). 


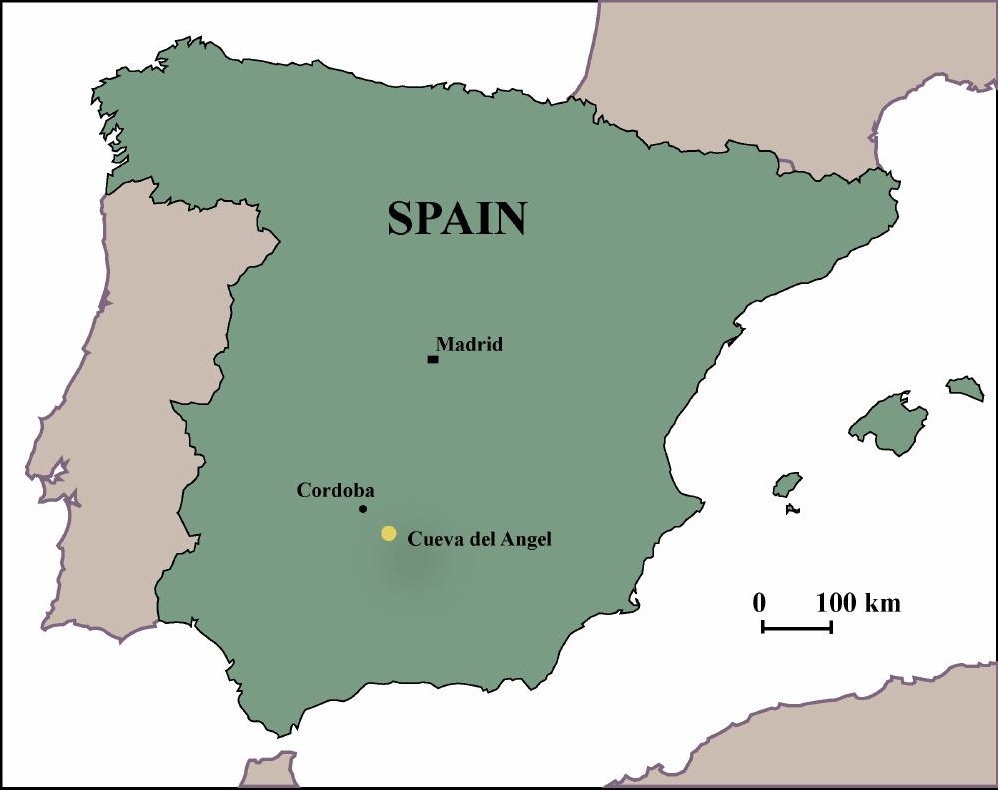




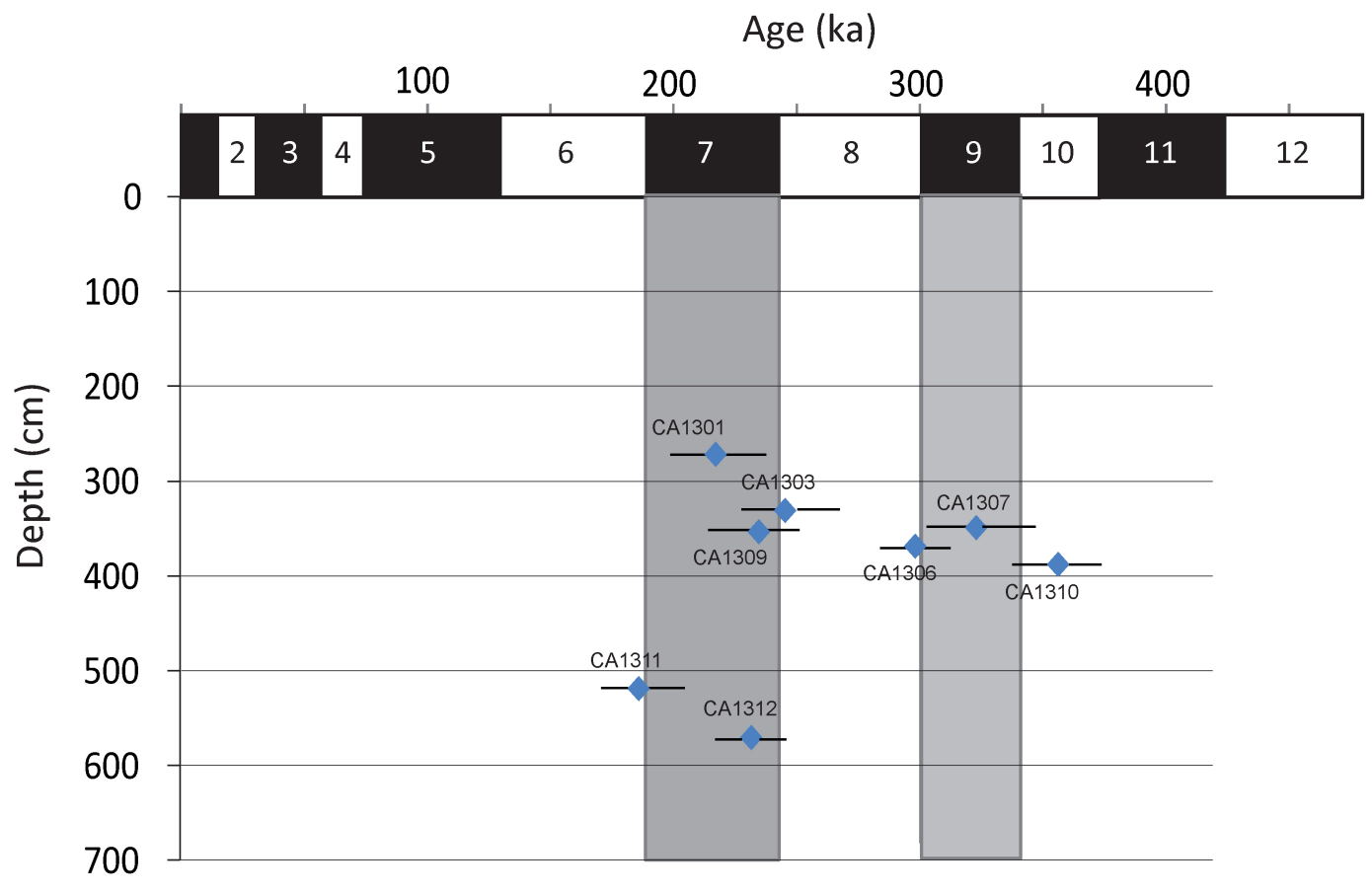




\begin{tabular}{|c|ccc|c|c|c|c|c|c|c|c|}
\hline Sample & ${ }^{238} \mathrm{U} \mathrm{ppb}$ & \pm & ${ }^{234} \mathrm{U} /{ }^{238} \mathrm{U}$ & \pm & ${ }^{230} \mathrm{Th} /{ }^{234} \mathrm{U}$ & \pm & ${ }^{230} \mathrm{Th} /{ }^{232} \mathrm{Th}$ & \pm & Age $(\mathrm{ka})$ & \pm \\
\hline CA\#6 & 37.5 & 0.2 & 1.014 & 0.011 & 1.022 & 0.012 & 96 & 0.9 & $\mathrm{NC}$ \\
$\mathrm{CA \# 1}$ & 42.2 & 0.3 & 1.005 & 0.011 & 1.000 & 0.013 & 121 & 1.6 & $>450$ \\
\hline CA9504 & 146 & 14 & 1.086 & 0.036 & 0.679 & 0.029 & 63 & 6 & 121 & 11 \\
CA9507a & 53 & 5 & 1.050 & 0.044 & 1.055 & 0.054 & $>100$ & 10 & $\mathrm{NC}$ & \\
CA9507b & 57 & 6 & 1.008 & 0.049 & 1.033 & 0.049 & 22 & 2 & $>370$ \\
\hline
\end{tabular}




\begin{tabular}{|c|ccc|ccc|c|c|c|}
\hline & \multicolumn{3}{|c|}{ 234U/238U } & \multicolumn{3}{c|}{ 230Th/234U } & \multicolumn{3}{c|}{ Sediment } \\
\cline { 2 - 9 } Samples & enamel & dentine & cement & enamel & dentine & cement & $\mathrm{U}(\mathrm{ppm})$ & Th (ppm) & $\mathrm{K}(\%)$ \\
\hline \hline CA1301* & $1,508 \pm 0,143$ & $1,004 \pm 0,037$ & & $0,777 \pm 0,077$ & $0,475 \pm 0,040$ & & $1,22 \pm 0,05$ & $0,779 \pm 0,07$ & $0,114 \pm 0,01$ \\
CA1303 & $0.995 \pm 0,225$ & $0,987 \pm 0,165$ & $1,156 \pm 0,118$ & $0,850 \pm 0.347$ & $0,937 \pm 0,161$ & $0,682 \pm 0,068$ & $0,538 \pm 0,05$ & $2,036 \pm 0,08$ & $0,248 \pm 0,01$ \\
CA1306* & $1,325 \pm 0,230$ & $1,282 \pm 0,031$ & & $0,933 \pm 0,165$ & $0,740 \pm 0,030$ & & $0,815 \pm 0,07$ & $2,214 \pm 0,11$ & $0,312 \pm 0,01$ \\
CA1307* & $1.300 \pm 0.394$ & $1,179 \pm 0,042$ & & $0.786 \pm 0.217$ & $0,602 \pm 0,030$ & & $0,815 \pm 0,07$ & $2,214 \pm 0,11$ & $0,312 \pm 0,01$ \\
CA1309* & $1,613 \pm 0,232$ & $1,225 \pm 0,108$ & & $0,755 \pm 0,120$ & $0,647 \pm 0,059$ & & $0,619 \pm 0,07$ & $1,612 \pm 0,09$ & $0,214 \pm 0,01$ \\
CA1310 & $0,807 \pm 0,245$ & $1,066 \pm 0,137$ & $1,218 \pm 0,102$ & $0.940 \pm 0.320$ & $1,01 \pm 0,105$ & $0,941 \pm 0,062$ & $0,541 \pm 0,07$ & $2,040 \pm 0,11$ & $0,315 \pm 0,01$ \\
CA1311 & $1,285 \pm 0,150$ & $1,157 \pm 0,049$ & $1,302 \pm 0,032$ & $0,853 \pm 0,126$ & $0,514 \pm 0,032$ & $0,348 \pm 0,016$ & $0,951 \pm 0,06$ & $3,157 \pm 0,09$ & $0,549 \pm 0,01$ \\
& & & & & & & $1.2 \pm 0.12$ & $3.5 \pm 0.40$ & $0.36 \pm 0.04$ \\
CA1312 & $1,078 \pm 0,184$ & $1,285 \pm 0,073$ & $1,299 \pm 0,117$ & $0,850 \pm 0.350$ & $0,714 \pm 0,055$ & $0,620 \pm 0,053$ & $1,061 \pm 0,08$ & $2,506 \pm 0,11$ & $0,299 \pm 0,01$ \\
& & & & & & & $1.2 \pm 0.12$ & $3.9 \pm 0.40$ & $0.31 \pm 0.03$ \\
\hline
\end{tabular}




\begin{tabular}{|c|c|c|c|c|c|c|c|c|c|c|c|c|c|c|}
\hline \multirow[t]{2}{*}{ Samples } & \multirow[t]{2}{*}{ Beds } & \multirow[t]{2}{*}{ Square } & \multirow[t]{2}{*}{ Depth (cm) } & \multicolumn{3}{|c|}{$\mathrm{U}(\mathrm{ppm})$} & \multirow[t]{2}{*}{ DE (Gy) } & \multirow{2}{*}{$\begin{array}{c}(\beta+\gamma) \text { sed }+ \text { cosmic dose } \\
(\mu \mathrm{Gy} / \mathrm{a})\end{array}$} & \multirow{2}{*}{$\begin{array}{c}(\alpha+\beta) \text { internal dose } \\
(\mu \mathrm{Gy} / \mathrm{a})\end{array}$} & \multirow{2}{*}{$\begin{array}{c}\text { Total dose rate } \\
(\mu \mathrm{Gy} / \mathrm{a})\end{array}$} & \multicolumn{3}{|c|}{ p-value } & \multirow{2}{*}{$\begin{array}{c}\text { ESR/U-series } \\
\text { ages (ka) }\end{array}$} \\
\hline & & & & enamel & dentine & cement & & & & & enamel & dentine & cement & \\
\hline CA1301* & I level 6 & $\mathrm{H} 7$ & 298 & $0.16 \pm 0.01$ & $2.51 \pm 0.09$ & & $71.2 \pm 4.1$ & $275 \pm 23$ & $48 \pm 10$ & $323 \pm 29$ & $-0.67 \pm 0.07$ & $0 \pm 0.36$ & $0 \pm 0.36$ & $220 \pm 20$ \\
\hline CA1303 & IV level 10 & H8 & 351 & $0.04 \pm 0.02$ & $0.31 \pm 0.04$ & $1.01 \pm 0.09$ & $70.2 \pm 2.3$ & $277 \pm 22$ & $16 \pm 6$ & $293 \pm 24$ & $-0.92 \pm 0.05$ & $-0.92 \pm 0.05$ & $0 \pm 0.1$ & $244+21 /-18$ \\
\hline CA1306* & VI level 5 & G8 & 385 & $0.05 \pm 0.03$ & $2.82 \pm 0.08$ & & $108.9 \pm 3.3$ & $325 \pm 24$ & $46 \pm 12$ & $371 \pm 33$ & $-0.81 \pm 0.06$ & $-0.68 \pm 0.19$ & $-0.68 \pm 0.19$ & $294+22 /-19$ \\
\hline CA1308** & VII level 1 & I8 & 367 & $0.03 \pm 0.01$ & $0.66 \pm 0.04$ & $1.07 \pm 0.05$ & $72.2 \pm 4.1$ & & & n.c. & & & & \\
\hline CA1309* & VII level 4 & H8 & 375 & $0.04 \pm 0.02$ & $0.57 \pm 0.04$ & & $63.4 \pm 2.1$ & $259 \pm 21$ & $18 \pm 9$ & $277 \pm 23$ & $-0.57 \pm 0.32$ & $-0.31 \pm 0.20$ & $-0.31 \pm 0.20$ & $230+21 /-19$ \\
\hline CA1310 & VIII level 8 & G8 & 395 & $0,05 \pm 0.01$ & $0.84 \pm 0.08$ & $1.09 \pm 0.07$ & $112.9 \pm 5.8$ & $292 \pm 23$ & $32 \pm 10$ & $324 \pm 25$ & $-0.96 \pm 0.02$ & $-0.87 \pm 0.01$ & $-0.91 \pm 0.02$ & $350+29 /-25$ \\
\hline CA1311 & XV level 7 & K8 & 518 & $0.07 \pm 0.03$ & $1.79 \pm 0.07$ & $3.52 \pm 0.1$ & $83.4 \pm 3.4$ & $418 \pm 28$ & $38 \pm 10$ & $456 \pm 30$ & $-0.92 \pm 0.04$ & $0 \pm 0$ & $0 \pm 0$ & $183+13 /-12$ \\
\hline CA1312 & XVI level 1 & K8 & 573 & $0.07 \pm 0.03$ & $0.93 \pm 0.05$ & $2.48 \pm 0.19$ & $89.0 \pm 2.3$ & $349 \pm 25$ & $36 \pm 10$ & $385 \pm 27$ & $-0.92 \pm 0.04$ & $-0.65 \pm 0.03$ & $0 \pm 0$ & $232+18 /-16$ \\
\hline
\end{tabular}

